\title{
Parque Madureira: Exceptional or Merely Good in Comparison?
}

Bryan McCann

\section{Introduction}

How good is the Parque Madureira? And for whom is it good? Of all the urban interventions transforming Rio de Janeiro in the run-up to the 2016 Olympics, Parque Madureira is the only one that has consistently garnered praise and prizes from urban planners, both in Brazil and internationally. What explains this enthusiasm, and is it justified?

Parque Madureira brings much-needed public leisure space to a denselypopulated, under-served swathe of low-income neighborhoods on the city's north side. Residents from all over the North Zone have been flocking to the park on weekends. But over 800 favela homes, along with the community gardens behind them, were removed to make way for the park. Urbanists have vociferously resisted favela removal associated with Olympic development elsewhere in the city, but most seem to have accepted the social costs associated with the construction of Parque Madureira. Representatives of social movements in contrast, have condemned the Parque Madureira removals as one more abuse perpetrated on Rio's poor and working-class residents in the midst of Olympian frenzy. And many of the residents of the favela removed to make way for the park want to be included in Olympic upgrading, rather than pushed further to the margins. As one former resident of the favela put it, "We're not fighting against this park. What I really want is to come to the park and have fun 
there. But I want the pleasure of leaving the park and not having to take two buses to get to my house" (Joseph, 2011).

Is Parque Madureira an outlier, a positive aberration in the midst of a generally negative urban transformation? Or is it the best of a mixed bag, with some of the same strengths and weaknesses as other current interventions, albeit perhaps more of the former than the latter? These questions have broader implications. If Parque Madureira is an outlier, then it does not really tell us much about the larger transformation of Rio de Janeiro, except what might have been, if the whole thing had been approached more sensibly. If it is the best of a mixed bag, then it suggests urbanists may need to temper both their optimism about Parque Madureira and their pessimism about the other interventions.

Either way, this is an important case for evaluation of favela policy. Favela removal as an urban-planning tool was largely off the table in Rio de Janeiro from the early 1980s through 2011, when it came back into play in the midst of planning for the mega-events of World Cup 2014 and the 2016 Olympics (Magalhães, 2013). If urbanists agree that Parque Madureira is a success, does that mean favela removal can in some cases be justified by the larger public good? If so, what are the conditions that might satisfy that justification and have they been met in this case?

\section{The Setting}

Madureira is one of Rio's most densely-populated neighborhood. It is 97\% urbanized, characterized by a tight cluster of low-rise apartment buildings, rowhouses and commercial establishments. The light-industrial factories which characterized the neighborhood fifty years ago are for the most part gone, replaced by shopping centers, fast-food franchises and auto-repair shops. For over a century, the center of the 
neighborhood has been the Mercadão Madureira, an extensive warren of fruit and vegetable stands, dried-goods purveyors, budget clothing and novelty shops.

Just east of the Mercadão Madureira rises a series of hills, a northerly spur of the Tijuca escarpment that divides the northern and southern halves of Rio de Janeiro. A chain of favelas occupies the lower flanks of these hills, most notably Serrinha, one of Rio's oldest favelas. Serrinha has long been a cultural hotbed. It played a key role in nurturing early samba, and is home to the Império Serrano samba school, one of the city's most beloved. Serrinha has also long been noted for jongo, folia de reis and other forms of Afro-Brazilian tradition. Over the past fifteen years, jongo from Serrinha tradition, in particular, has reemerged as a marker of local identity and a cultural attraction.

Serrinha and neighboring favelas have also been hotly disputed territories in turf wars between competing criminal factions and the military police. As elsewhere, these turf wars have been cyclical, with periods of horrific violence followed by periods of apparent calm. Police reform and the rise of the UPP (Unidade de Polícia Pacificadora) strategy have not dramatically transformed this cyclical violence in greater Madureira. Several competing factions continue to occupy terrain in Serrinha, Terço, Cajueiro and other local favelas, and to do battle with military police.

Two commuter rail lines run through Madureira, linking the neighborhood both to central Rio and to outlying neighborhoods. One of these lines stretches directly north, connecting Madureira to the neighborhoods of Turiaçu, Rocha Miranda, Honório Gurgel and Guadalupe, before crossing the Avenida Brasil highway and continuing north towards the neighboring municipality of Belford Roxo. Parque Madureira runs adjacent to this rail line. At its current extent, it passes through Madureira and Turiaçu into Rocha Miranda. When fully completed, it will run all the way to Guadalupe. These neighborhoods are as densely populated as Madureira, but have a higher concentration 
of residential occupation and fewer commercial establishments. Collectively, these neighborhoods form the core of the city's 15th Administrative Region XV (Região Administrativa XV). With a population over 350,000, it is one of the city's largest administrative regions, and is predominantly lower-middle-class and low-income.

Before Parque Madureira, there was no public park to speak of in this vast region of the city. There are a few "praças" at the junction of major avenues, which are mostly barren traffic islands. From the air, it appears that there is extensive green space just west of this dense urban patch, but this territory is under direct military control and is off limits to civilians. The peaks of the hills just east of Madureira are also uninhabited, but as these are inaccessible by public transportation and lie above favelas characterized by violent turf conflict, they have not offered any meaningful leisure space for the surrounding population (dos Santos, 2012).

\section{The Vila das Torres}

To say this region needed a park would be a vast understatement. Public leisure space was consistently near the top of political demands made by local residents. The cult of the body beautiful is a prominent marker of carioca culture, and public pursuit and display of fitness has grown increasingly important over the past decade. The South Zone and the western beach neighborhoods of Barra da Tijuca have extensive areas for public leisure, beginning with kilometers of golden sands, and including jogging and bicycle paths, public soccer and volleyball courts, leafy parks and numerous exercise areas outfitted with special equipment designed for senior citizens.

Even those areas of the North Zone adjacent to the Guanabara Bay benefited from some investment in public leisure space, notably at the Piscinão de Ramos, a man-made beach and salt-water pool several kilometers east of Madureira. South-zoners may turn 
up their noses at the Piscinão de Ramos, but it offers an extensive stretch of beach to local residents. (Regular reports of insufficient water treatment do little to deter visitors.) When the Piscinão, or Big Pool, opened in 2001, it substantially upgraded public leisure opportunities in an underserved area with a high concentration of favelas. Subsequent investment in other public waterfront fitness areas along the Guanabara expanded options for local residents. Improvements in the bayside area of the North Zone meant that until 2012, Madureira and the rest of the 15th Administrative Region, farther inland, was the worst-served area of the city in terms of investment in public leisure and fitness.

As is often the case, however, the neighborhood that most needs a park (or a school, or a hospital, or any other public facility) is the hardest place to put one, because all the space is already taken. The state government of Rio de Janeiro built the Piscinão de Ramos on land reclaimed from the Guanabara Bay. Landlocked Madureira offered no such opportunity.

What Madureira had, however, was a long strip of land in the shadow of highvoltage electrical towers, running parallel to the rail line that connects Madureira and Guadalupe. This strip was only 100 meters wide but ran 1.5 kilometers due north, where it was cut off by a highway viaduct passing over the railroad tracks. (A similar strip continues north of the viaduct for another 2.5 kilometers.)

This open space presented the only opportunity for a public park in Madureira. The presence of the high-voltage towers was an obstacle but not an insuperable one, as these could be clustered more tightly along the eastern fringe of the strip, leaving the remainder open for the construction of a park. Light, the private energy company that provides electricity to Rio de Janeiro, owned both the high-voltage towers and the land they rested upon, and could be persuaded to cede the land to the municipality. The larger transformation of the city in the run-up to the Olympics, and the enthusiasm of 
the municipal government in branding Rio de Janeiro as a city defined by fitness and public leisure, made funding available for construction of an extensive park.

As is often the case, the primary obstacle was neither geographical nor financial but political. Squeezed between the high-voltage towers and the railroad tracks was a long, narrow favela known as the Vila das Torres. Its name referred to the high-voltage towers, not to the favela homes themselves. Most of these were two stories high, standing shoulder to shoulder along the 1.5 kilometer stretch of track between the Mercadão de Madureira and the highway overpass. They occupied the eastern edge of the strip-precisely the area designated for the high-voltage towers, in order to make way for the park in the rest of the strip. City officials determined that building the park required destruction of 897 of these homes (Costa Silva, 2013).

In this regard-and it is surely one of the most decisive-the construction of Parque Madureira was typical of the broader transformation of Rio de Janeiro. The favela removal undertaken to make way for the park was by turns baffling and harrowing for the favela residents. The municipal government made promises it could not keep and threats it never would have made to formal property owners. It deliberately low-balled residents, cajoling as many as possible into leaving quickly for uncertain benefits, then negotiated more generous settlements with holdouts. And it justified removal by evoking the Olympian transformation of Rio de Janeiro, a transformation in whose benefits the favela residents would not share.

As in most cases, property ownership in Vila das Torres was nebulous, and characterized by several different kinds of informality. Most of the favela homes straddled Light's property and the railroad right-of-way. As a private utility corporation acting with the concession of the state government, Light is a private landowner, but one whose claim depends heavily on close relationships with municipal and state government. Light promptly agreed to turn over its claim to most of the strip of open 
land in return for clear control over the eastern fringe and governmental funding for relocation of the high-voltage lines. Light effectively removed itself from any direct involvement in the process of removal, leaving residents to negotiate directly with municipal government (idem, 2013).

The railroad right-of-way presented a clearer legal situation, as Brazilian federal law prohibits private construction within such territory. The state of Rio, however, has, on prior occasions offered favorable terms to some residents of favelas on railroad rights-of-way. For some residents, this constituted a precedent suggesting they would not be evicted without a decent settlement. (Residents of favelas on the right-of-way of the light-rail municipal metro, in contrast, have suffered some of the most harrowing processes of removal.)

Closer to the Mercadão Madureira, some of the favela homes sat entirely on private land of uncertain title. This presented a more complicated legal situation. Longterm occupants of such homes could conceivably file claims to formal property ownership based on the doctrine of usucapião, or adverse possession. This would potentially put the municipal government in the position of fighting dozens of simultaneous legal claims in order to carry out removal. Historically, favela removal that unfolds gradually on a case-by-case basis proves unsuccessful, as new residents find ways to occupy vacated spaces, even in highly forbidding circumstances. Perhaps not surprisingly, the city largely shied away from this area, limiting the park and the removal associated with it to the Light lands and the railroad right-of-way.

In one crucial regard, the Vila das Torres was an atypical favela, and that was in its geographical disposition. Vila das Torres was approximately fifteen meters wide and 1500 meters long. One advantage of this array was that it made the Vila das Torres relatively unattractive to criminal interest groups. It offered no place to hide and no perch to defend. Perhaps as a result, Vila das Torres did not apparently suffer violent 
turf occupation. At the same time, elongation worked against the consolidation of a vigorous sense of shared community interests. Residents of the northern end had little contact with those at the southern end. This made it easier for municipal officials to pressure individual residents to accept initial offers and move on, rather than resisting. Vila das Torres had a neighborhood association, but city officials effectively maneuvered around it, negotiating directly with individual residents (idem, 2013).

In December, 2009, residents first learned of imminent plans for removal and the construction of a park. They heard initial rumors that the city planned to construct a 540-unit apartment complex at the north end of the park, and that favela residents would be moved to these units (Joseph, 2010).

These rumors were entirely plausible. 2009-2011 turned out to be the high watermark for aspirations of transforming Rio in a socially-responsible way. For the first time since the mid-1970s, the federal government seemed to be paying attention to Rio de Janeiro, and was investing heavily in both improved security and in infrastructure and social services targeted at low-income populations. And for the first time in as many years, municipal, state and federal government were collaborating on reforms, rather than actively working to undermine each other. Favelas like Santa Marta and Rocinha were the direct beneficiaries of this brief moment, in the form of infrastructural upgrading and expanded services. Residents of these favelas were often uneasy about such reforms, fearing they might lead towards gentrification. But none faced direct removal, and many reaped windfalls.

In the case of Vila das Torres, however, such hopes did not materialize. The planned apartment buildings turned out to be just a rumour. Instead, by May of 2010, city officials were summoning residents individually to the Secretariat of Habitation, in an imposing, modernist high-rise municipal building along the city's central Avenida Getúlio Vargas. The city offered them apartments in a new complex in Realengo, fifteen 
kilometers west of Madureira. These apartments were among the first built under a new federal program called Minha Casa Minha Vida (My House My Life), designed to stimulate construction of low-income housing throughout the nation ${ }^{1}$. Residents were informed they would only need to pay monthly water and electricity bills. 290 apartments in Realengo were ready for occupancy, and the city encouraged residents of Vila das Torres to move immediately. The city also made available fifty individual homes in Realengo for those moving out of Vila das Torres. Demolition of favela homes began that same month (Joseph, 2011).

That still left approximately 500 occupied homes in Vila das Torres. Thus began a slower process of resistance and negotiation (albeit one still relatively rapid by the standards of Rio de Janeiro). Remaining residents initially sought to avoid removal. City officials sought to persuade residents not only with individual payouts, but with an invocation of the common good: they argued that Madureira desperately needed a park, one that could only be constructed with the removal of Vila das Torres. They further suggested that voluntary acceptance of relocation would be a contribution not only to the common good, but to sustainability. This term was quickly becoming a buzzword of carioca politics, one that would become increasingly common in justifications of Olympian transformation over the next five years.

One irony of this appeal was that some residents of Vila das Torres were already engaged in sustainable practices. The open space under the high-voltage towers was neither barren nor fallow. Instead, much of it was cultivated in community gardens by residents of Vila das Torres. The produce of these gardens was a vital part of their sustenance, offering a wider variety of fruit, vegetables and medicinal herbs than they were likely to be able to afford in any market. And gardening itself constituted a vital,

1 "Minha Casa Minha Vida: An Overview of New Public Housing in Rio," RioOnWatch, http://www.rioonwatch.org/?p=14887

3RASILIANA- Journal for Brazilian Studies. Vol. 4, n.2 (2016). ISSN 2245-4373. 
restorative leisure activity for several of the local residents, who could not imagine being separated from the plots they had cultivated for years. If farming in the immediate vicinity of high-voltage towers was neither strictly organic nor entirely safe, these were niceties with which the residents of Vila das Torres could not afford to concern themselves.

For city planners, however, the potential benefits of a park that would serve tens of thousands of area residents vastly outweighed the value of small-scale sustainable practices of a few favela residents. City officials never mentioned the community gardens in the removal process and made no gesture of offering similar opportunities in Realengo or anywhere else.

Negotiation, removal and demolition of favela homes played out over the next twenty months, through early 2012. That process was haphazard and arbitrary-again, common characteristics of favela removal. Rio's municipal law stipulates that, in cases where relocation is unavoidably necessary, residents must be relocated in areas close to their existing place of residence or work. Relocation fifteen kilometers away in Realengo, which lacks the commercial vitality of Madureira, clearly did not meet these conditions (Cardoso, Nunes, Araujo et al. 2013). Those residents who did not resettle in Realengo, moreover, were offered payouts insufficient to buy or rent comparable homes in the Madureira area. ${ }^{2}$

Some residents took what they could get quickly, while others called upon the services of the Rio de Janeiro state Public Defender's office, as well as on the Popular Counsel, a civil-society organization granted a consultative role in municipal policy. The Public Defender and the Popular Counsel helped exert pressure on city government. A

\footnotetext{
2 “Comunidades removidas em função de obras viárias e da construção dos corredores dos transportes dos BRTs Transcarioca, Transoeste e Transolímpica,’Olympi(c)Leaks: ObrasMobilidade,” http://olimpicleaks.midiatatica.info/wikka/ObrasMobilidade
} 
few residents of Vila das Torres fared relatively well, securing advantageous payouts. The reasoning behind differentiated payouts, however, remained a mystery to most residents and perhaps to city officials themselves. It was not clear why some residents received payouts of 20,000 reais, while residents of comparable homes received 55,000. (Even 55,000, it bears noting, was far below the cost of a two bedroom apartment in a nearby building) (Bahia, 2013).

Many of those who moved to the new apartments in Realengo, meanwhile, were unhappy, primarily with the location and its offerings. The rich and varied commercial life of Madureira offered numerous low-income employment opportunities. The Mercadão de Madureira itself employs thousands of people, many of them local residents. Realengo, in contrast, offers relatively little access to commercial employment, and is a long bus ride from the city center (Cardoso, Nunes, Araujo et al. 2013).

Residents of the small patch of favela homes closest to the Mercadão, those who were not removed, ended up with the most favorable situation. They have been able to hold onto the investment they had made in their homes over time. And those homes now overlook a beautiful new park. These residents are among the immediate beneficiaries of the rising property values in the neighborhood stimulated by that park's creation. The contrasting fates of Vila das Torres residents exemplify the arbitrary processes and contingent consequences of favela removal.

\section{Parque Madureira}

Removal of Vila das Torres and relocation of the high-voltage lines left a $50 \mathrm{~m}$ by $1.5 \mathrm{~km}$ strip of open land for the creation of the park-a golden opportunity for any urban planner, but also a huge risk, given the controversy and high expectations. The Municipal Secretariat of Public Works was charged with managing and developing the 
project, collaborating with a private landscape architecture firm on design and execution. The Public Works Secretariat placed civil engineer Mauro Bonelli in charge of the project. This was a bold move, one that turned out brilliantly. Bonelli was relatively young and inexperienced for managing a massive, transformational project. His plans for Parque Madureira doubled as his Master's thesis for the degree in Urban and Environmental Engineering at PUC-Rio he completed in May of 2013 (Chagas Bonelli, 2013).

There are more experienced engineers in the city's Public Works department. One advantage of the plethora of projects underway in the run-up to the Olympics, perhaps, is that there are so many major public construction projects underway concurrently that the city has been forced to offer opportunities to innovative and enterprising engineers at relatively early stages of their careers. In the case of Parque Madureira, this meant turning over responsibility for a major project to a young engineer with an innovative understanding of environmental sustainability and an ability to balance complex demands from multiple sectors.

The city hired architecture firm Ruy Rezende Arquitetura-known in the trade by the lowercase acronym rra-to design the park's features and to collaborate with Bonelli and the Public Works department on execution. This created a close publicprivate partnership between Bonelli and the architects at rra, particularly Filipe Merem, the project's urban planning coordinator, Heloísa Normando, the landscape architecture coordinator, and André Costa, the architecture coordinator. (As a park woven into the surrounding fabric of the city, and including both extensive landscaping as well as several major buildings and numerous smaller constructions, Parque Madureira required careful oversight in all these sectors, and cooperation between them.) It is difficult for the outside observer to parse the contributions of this partnership, identifying responsibility for specific contributions. It is apparent that the team merged 
Bonelli's concerns for environmental sustainability and feasibility with rra's vision for a park designed for fitness, relaxation and flexible use (Rezende, 2013).

The result is a state-of-the-art park. It fulfills the current best practices of environmental sustainability while responding in innovative ways to the needs of the local population-or at least the local population left after the removal of Vila das Torres. It substantially upgrades the urban geography of the surrounding region, offering new options for leisure and circulation. And it meets these goals within a budget that is far lower than monstrous, less-successful projects elsewhere in the city.

Parque Madureira is also state-of-the-art in another sense, one more directly linked to the broader transformation of the city. The particular vision of fun and fitness embodied by Parque Madureira exemplifies the municipal government's strategy for branding the city. Parque Madureira does this more successfully than any of the other projects currently underway. Among these projects, Parque Madureira is exceptional in meeting the needs of a low-income population, a priority often overlooked elsewhere. But the vision of the park is perfectly in keeping with the municipal government's broader vision for the city.

In the short term, this has been one of Parque Madureira's greatest strengths. Popular acclamation for the park suggests that most cariocas are enthusiastic about the goals of the city's Olympian transformation, as long as they are included among the beneficiaries of that transformation, rather than bearing all the costs while being excluded from most of the benefits. And the municipal government has claimed the park as "the most important legacy" of the Olympian transformation-a pride that carries with it a commitment to maintenance, at least for now.

Will this exemplification of the city's re-branding strategy continue to be a strength in the long run? This is more difficult to assess. A massive public park should be designed for future generations as much as for the current moment. Parque 
Madureira has enough built-in flexibility that it may remain vital through changing trends in popular use. But its emphasis on installations that are popular in 2015 may prove a liability in the long run. Parque Madureira as it currently exists is anchored by an amphitheater for samba performance at one end and a skate park at the other. Samba and skateboarding suit the current mood. Whether the park and its various components will adapt successfully to changing tastes is another question.

\section{Strengths and Major Features of Parque Madureira}

Bonelli and the architects from rra designed the park in four sectors, moving from south to north along the narrow strip of the park, each emphasizing a different kind of use. The first and southernmost sector is the Samba Plaza, featuring the large concrete amphitheater. The amphitheater, bleachers and surrounding apron can accommodate approximately 3,000 spectators. This popular-music performance space builds on the historic importance of the samba schools Portela and Império Serrano, and Madureira's larger tradition as a samba redoubt. Portela and Império Serrano each have their own performance spaces nearby, and the amphitheater in Parque Madureira complements rather than supplants them.

The second sector is the Contemplative Park, featuring green space, an ample public plaza with a rent-a-bike station, and an extensive, wheelchair-accessible botanical garden. This sector also includes a large media center called the Nave do Conhecimento, or Vessel of Knowledge, containing public-access computers and digital media labs. The glazed outer wall of the Vessel doubles as a screen for open-air cinema. The Vessel responds to the emphasis on digital inclusion in current political rhetoric in Rio-its goal is to strengthen the citizenship of the lower-income residents of Madureira by offering them access to the tools of digital expression, communication and education. (It 
goes without saying that the Vessel will remain useful only as long as its equipment can be maintained both up-to-date and accessible.)

Finally, this sector includes an Environmental Education Center, offering classes and sessions for school visits and local residents. The Environmental Education Center doubles as an administrative building, housing the controls for the park's extensive irrigation, electrical, closed-circuit television and security networks. The Center is also meant to exemplify environmental best-practices, most visibly through its plant-covered green roof and walls.

The third sector is the Sports Sector, featuring the park's most popular installations, the Water Stairs and the Skate Park. The Water Stairs are a simple but ingenious tiered fountain, allowing visitors to splash in a shallow pool, stand under a cool waterfall, or play in water cascading down concrete steps. The water is treated and recycled. Madureira is one of the hottest neighborhoods in a tropical city, and the Water Stairs are understandably beloved (de Sousa, 2013).

The Skate Park is the second-largest in Brazil, and reputedly the most up-to-date, with a half-pipe, banked walls, a bowl, a pool, a quarter-pipe, a jump and several other features approved for national and international skateboarding competitions. Skateboarding has grown exponentially in popularity in Rio de Janeiro in the last decade, particularly in the North Zone, and the Skate Park responds in a timely way to this rising demand. Adjacent to the Skate Park are a small, artificial-turf soccer field, two multi-sports courts and a beach volleyball court.

The fourth sector contains the Arena Carioca Fernando Torres, a venue for concerts and theater, seating approximately 330 indoors or 1,500 outdoors. (The stage rotates, allowing for both indoor and outdoor use.) This sector also includes a sewage treatment plant, a key component of the park's goal of sustainability, treating the waste 
from the numerous public toilets around the park. It also includes a station for the Municipal Guard, a lightly-armed police force charged with maintaining public order.

A bicycle path and an exercise circuit wind through the park, and an access road along the east side facilitates internal circulation and limited parking. The park is wellintegrated into the urban fabric along its west side, with broad, accessible entrances at street level. These are well-designed meeting points and places of congregation, facilitating easy passage from the streets into the park and back out. Accessibility, circulation and integration into the surrounding neighborhood are among the park's greatest strengths.

All of the installations are designed for maximal environmental efficiency. For a park that welcomes 40,000 visitors on a typical weekend, Parque Madureira's water and energy uses are surprisingly low, its sewage limited and well-treated, and its trash sorted immediately into organic and various categories of recyclables.

Given these strengths, it is not surprising that the park has not only attracted local visitors but won international recognition (Castilho). ${ }^{3}$ The park is AQUA-certified (Alta Qualidade Ambiental, or High Environmental Quality) by the Fundação Vanzolini, Brazil's most prestigious designation of environmental standards. It won the Urban Design-Built Prize from Re-Thinking the Future, an independent, global architectural awards organization ${ }^{4}$. It received an Honorable Mention Award from the Rio de Janeiro chapter of the Brazilian Architectural Institute. And it has been the most important component in rra's prize-winning portfolio in several other environmental

\footnotetext{
${ }^{3}$ Rose Castilho, “Oásis verde Em meio à selva de pedra do bairro de Madureira, no Rio de Janeiro, nasce um respiro para convivência, lazer e sustentabilidade," Revista Green Building, 02, http://www.revistagreenbuilding.com.br/projeto.php?id=1

${ }^{4}$ Re-Thinking the Future, First Award, Urban Design Built, 2014. http://www.rethinkingthefuture.org/portfolio/madureira-park-rra/
}

RRASILIANA- Journal for Brazilian Studies. Vol. 4, n.2 (2016). ISSN 2245-4373. 
awards competitions. ${ }^{5}$ The park was also recognized by New York Times art critic Michael Kimmelman, in an influential 2013 article, as the only bright spot in the otherwise misguided Olympian transformation of Rio de Janeiro (Kimmelman, 2015).

\section{Weaknesses and Comparisons}

The park opened to great acclaim in mid-2012 (Sousa, 2014). Frequency of visitors has risen and fallen over the last three years, peaking on weekend evenings throughout the year, dropping to lows on summer weekdays. Among the few complaints of parkgoers has been the lack of shade, but this may be more a growing pain than a design flaw, as the park's young trees are still maturing. Bonelli and rra have nonetheless attempted to respond, planning installation of shade-giving trellises. Frequency has also dropped in periods of renewed turf wars between the criminal organizations that remain active in nearby favelas. The park designers are utterly powerless to ameliorate this situation. But it does remind one that the rebranding of Rio de Janeiro depends on a fragile, controversial security initiative of uncertain outcome.

Of all the park's major features, the Arena Carioca Fernando Torres has been the least successful, thus far. Not coincidentally, it is also the one that emerges from topdown cultural directives, rather than responding to expressed desires of the local population. The Arena is part of a network of four new municipal theaters on the north and west side of the city and is meant to democratize access to culture. This is undoubtedly a laudable goal, but while the skateboarders were already around, looking for a place to skate, the would-be theatergoers need to be inspired, and that is easier said than done. The Arena Carioca, like the other three theaters in the network, has run into obstacles faced by other public theater initiatives in Rio. Free productions, funded by the

\footnotetext{
5 "Premiações," http://www.rra.com.br/perfil/premiacoes
}

3RASILIANA- Journal for Brazilian Studies. Vol. 4, n.2 (2016). ISSN 2245-4373.

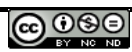


municipal government and private sponsors, are often perceived as being of lower quality, and struggle to attract viewers. The prices of ticketed spectacles, in contrast, are often beyond the means of the local population. The Arena Carioca has attempted to negotiate this challenge by offering admission to many shows for $\$ 1$, with mixed success.

It bears noting that one of Rio's most beautiful public theaters, the Teatro Armando Gonzaga, is only a few kilometers away, in the neighborhood of Marechal Hermes. In its five decades of existence, the Teatro Armando Gonzaga has never successfully solved the riddle of drawing a consistent theater audience on Rio's north side. The theater is usually vacant, and its few productions tend to be sparsely attended. The Arena Carioca Fernando Torres has a larger natural audience of parkgoers, but will face similar difficulties in sustaining audience frequency. In the meantime, theater professionals, at least, have been grateful for the opportunities provided by the new, subsidized public theaters.

As a work of landscape architecture, the park operates under great constraints. The design priorities of fitness, fun, accessibility and circulation all take priority over the kind of arboreal vistas and shaded glens that have traditionally marked park design. This marks a departure from the swooping geometry and vivid botanical color of the tropical modernism that defined carioca landscape architecture for over six decades.

Most of Parque Madureira is as flat as a parking lot and so chock-a-block with facilities and pathways that there is comparatively little botany. This is one of the few city parks whose creation reduced vegetation: the community gardens behind the Vila das Torres may have served a very small population, but they included more total green space than the current park. This is not necessarily a weakness. Wheelchair-users are among the most assiduous frequenters of the park, and deeply appreciate the winding pathways, the sensory gardens of planters at wheelchair-height, and the bathrooms and 
other facilities that are designed not merely to be wheelchair-accessible, but to offer delight and enjoyment to the wheelchair-bound. A park that satisfies both skateboarders and the disabled, while fulfilling sustainable goals, is a major achievement.

Plans for expansion, however, raise more serious questions. The extension of the park northwards through Guadalupe to the Avenida Brasil will triple the size of the park. The overall expansion of leisure space and options for recreation in the North Zone is good news. But the planned installations in the extended park double down on fun-and-fitness branding, posing significant challenges for continued funding, maintenance and adaptability.

The two key features of the new section will be an artificial beach and an artificial ski slope. Greater access to the beach has long been an aspiration of cariocas in the landlocked heart of the North Zone, and the new plans suggest that if these residents cannot get to the beach, then the municipal government will bring the beach to them. The enterprise will be similar to that of the Piscinão de Ramos, albeit under the aegis of municipal rather than state government, and even more extensive in area. The beach zone in Parque Madureira will include twelve artificial waterfalls, cascading treated and recycled water. This initiative responds to popular demand, but will require significant investment not only in construction but in maintenance. Given Rio's traditional disruptions and shifts in direction from one mayoral administration to the next, this is an uncertain prospect.

The ski slope by no means responds to popular demand. It is the kind of grandiose gesture known in Brazil as a projeto faraônico, an initiative worthy of the ancient Pharoahs. With the ski slope, Parque Madureira will move definitively from the category of a park meant for leisure and relaxation to an amusement park. Again, whether this is a flaw depends on one's priorities. As the great samba-school carnival designer Joasinho Trinta famously remarked, “Only intellectuals like misery. Poor 
people like luxury." Delivering a ski slope to the North Zone may turn out to be the kind of publicly-subsidized luxury that people love. Since the nineteenth-century, at least, amusement parks have been criticized by engaged intellectuals as distractions, the products of misguided priorities and political chicanery. But those same amusement parks tend to be remembered wistfully as cherished spaces of hard-won delight for those who enjoyed them in their prime.

They do have a prime, however, and that reminds us that they inevitably have a decline, as well. Decline tends to come far more quickly for amusement parks than it does for contemplative parks. In this regard, it is worth comparing Parque Madureira to several other noted parks in Rio, each emblematic of the moment of its creation.

The Quinta da Boa Vista is currently Rio's second-largest park-it will drop to third on the list once Parque Madureira reaches its full extension. The Quinta initially served as the gardens of the Palácio de São Cristóvão, the residence of Brazil's royal family through much of the nineteenth century. French landscape architect August François Marie Glaziou designed the gardens in 1869, blending European romanticism with tropical splendor. The gardens slope regally down from the majestic, neo-classical palace itself (now the National Museum of Anthropology), towards elegant ponds. The road to the front of the palace is framed by a shaded alleyway of sapucaias, a Brazilian hardwood. The slope behind the palace leads towards the city zoo, whose entrance preserves the nineteenth-century portico of the imperial palace. The Quinta became a public park early in the twentieth-century, and remains among Rio's most beloved and most-visited public spaces. The gardens look much the same as they did in 1869.

Glaziou also left his mark on the Passeio Público, a smaller park in the heart of the city. The Passeio Público is Brazil's oldest park, originally designed in the late 18th century in the geometric layout typical of the French royal gardens of that period. Glaziou radically redesigned the park, transforming it into a dense, enchanted glade. 
The Passeio Público feels much larger than it is, as each turn in its winding paths draws the viewer deeper into another shaded bower.

The Campo de Santana, a few kilometers away on the other side of the city center, opened as a public park at the tail end of the Brazilian Empire, in 1880. Its tropical romanticism is similar to that of the Passeio Público, with broader vistas and a larger central plaza. Both the Passeio Público and the Campo de Santana remain among the most-frequented parks in the city, leafy havens from the sweltering bustle of the surrounding streets.

The city's largest park is the vast Aterro do Flamengo, the crowning achievement of Brazilian modernist landscape architect Burle Marx. The terrain was created through a massive landfill project in the early 1960s (Aterro literally means landfill), reclaiming hundreds of acres from the Guanabara Bay. The landfill was intended to create space both for a new high-speed commuter route on the city's south side and for a new park. Carlos Lacerda, the governor who pushed through the project, was abundantly criticized for this "pharaonic project." The most prominent criticism was that the expensive park would serve only the middle-class residents who lived nearby, not the vast population of the city's poor who most needed recreational space. It is certainly true that Lacerda tended to prioritize middle-class interests. But in the case of the Aterro do Flamengo, his initiative ultimately yielded long-term benefits for cariocas of all classes.

This owes much to the vision of Burle Marx, who translated the clean curves of Brazilian modernist architecture into bright, pleasing tropical gardens. Marx designed the Aterro as a series of dales, a gently-corrugated topography spilling towards a golden beach, lapped by the waters of the bay. Graceful bridges, pocket gardens and stunning vistas of Rio's iconic Pão de Açúcar hill make a stroll through the Aterro an ever-shifting panorama of visual delight. Sports courts and bicycle paths provide ample recreational 
opportunities. The Aterro has changed somewhat more in its fifty years of existence than have the Campo de Santana and the Passeio Público, as new snack bars and fitness courses have altered Marx's original project. But it remains an iconic masterwork of Brazilian modernism. Like the Quinta, the Passeio Público and the Campo de Santana, the Aterro is among the city's most-frequented parks, a vital recreational space for the tens of thousands of cariocas who visit weekly.

Glaziou's tropical romanticism responded to the aspirations of the carioca elite in the second half of the nineteenth century, offering a languor meant to be savored at the pace of a slow stroll-an idyll for the idle, or those who wished to be. Burle Marx's tropical modernism captured the cool seduction of bossa nova Rio, leaning into the curves of the 1960s. Those ages are gone, but the parks remain inviting. Cariocas use them in ways Glaziou and Marx did not anticipate, but continue to find space for their own pursuits of reverie and relaxation in their folds.

Parque Madureira conforms to the culture of the moment, allowing the visitor to move seamlessly from one spectacle to another without constraint. Will it remain similarly vital two generations hence? Perhaps, but it is hard to imagine. Parque Madureira's presentist focus may turn out to be the hallmark of a new generation of carioca landscape architecture. When artificial ski slopes go out of style, that section of the park can be transformed into a trampoline zone or a virtual-reality adventure park or whatever trend comes next in public amusement-park design. Theoretically, the willingness to transform and replace major park installations, rather than expecting subsequent generations to adapt to an originalist vision, could turn out to be the park's greatest strength. But this presupposes a continued level of funding, commitment and renewed imagination that would be out of the ordinary in carioca administration. 


\section{Parque Madureira's Place in the Olympian Transformation}

When considered in the context of Rio's broader Olympian transformation, Parque Madureira is exemplary rather than atypical, as a quick survey of the other major projects in this transformation will demonstrate. A few blocks away from the southern end of Parque Madureira sits the Madureira Station of the city's new Transcarioca BusRapid Transit line. The Transcarioca cuts a diagonal line across the city from the international airport in the northeast to Barra da Tijuca in the southwest. The BRT line meets an immediate need for the Olympics, as it promises to facilitate rapid movement of tens of thousands of tourists from the airport to the principal Olympic venues. It also serves longer-term transportation needs, finally creating a rapid-transit option from Barra through the North Zone to the Ilha do Governador. And the price of transport is accessible to working-class cariocas, who will constitute the majority of ridership after the Olympics.

As a BRT line, the Transcarioca is inevitably less attractive than the urban-rail metro system on the eastern and southern perimeter of the city. Since the creation of the metro system in the 1970s, urban rail has primarily served the middle class, with the working class consigned to overcrowded, slow buses. The Transcarioca offers a new, intermediary modality, one that seems expressly tailored to the needs of the "emerging C class," - those rising from the working to the middle class. As recently as early 2013, the emerging $C$ class was seen as both the key sector and the principal beneficiary of Brazil's longest period of sustained economic growth in sixty years. Current economic and political challenges have revealed the fragility of that emergence, threatening to consign the $C$ class to secondary status once again. The Transcarioca seems to embody that delicate position. If well-funded and maintained, it will provide satisfactory but unlovely rapid transit in an underserved part of the city. 
The social costs of the Transcarioca, meanwhile, have been considerable. Thousands of residents of favelas and irregular subdivisions were uprooted to clear a path for the line. Like the residents of Vila das Torres, their fates were arbitrary and contingent, with some faring relatively well and many pushed farther towards the periphery with no recourse. Two other new BRT lines, the Transoeste and the Transolímpica, offer a similar balance of costs and benefits. Several expansion projects for existing highways round out Rio's Olympian transportation initiatives. Collectively, these should facilitate transportation for the few decades, and should provide more efficient connections between the heart of Rio in the southeastern corner of the municipality and the vast western precincts. They are unglamorous and controversial but conform to an understandable logic. Their emphasis on circulation and accessibility reflects some of the goals pursued on a more local scale in the Parque Madureira (Magalhães, 2009).

The Porto Maravilha Project is transforming the port district of downtown Rio de Janeiro. Once the heart of Rio's industrial sector, the port district fell into decadence in the process of Rio's deindustrialization, a decline only exacerbated by previous urban interventions, such as the construction of an elevated highway along the perimeter of the bay. Porto Maravilha has knocked down the elevated highway, creating a series of plazas, parks and local streets in its place, and opening a new tunnel for cross-town traffic. New museums, sports facilities and an aerial tram to the top of Providência Hill, overlooking central Rio, round out the project. Porto Maravilha is similar to Parque Madureira in its goals and vision, if not necessarily in its execution. Like Parque Madureira, it emphasizes fun and fitness, democratization of access to culture, circulation and accessibility. Again like Parque Madureira, it required uprooting lowincome residents in the neighborhoods of Gamboa, Saúde and Santo Cristo, and the partial removal of the Providência favela, one of Rio's oldest and best-known. 
Despite these similarities, Porto Maravilha has proven more controversial than Parque Madureira for at least three reasons. The first is that residents of Providência were able to mobilize allies in media and social movements far more effectively than were residents of Vila das Torres. Opposition to removal in Providência became one of the early flashpoints in growing popular hostility to Rio's Olympian makeover. That resistance successfully reshaped the project, reducing the removals carried out to clear a path for the aerial tramway (Globo, 2014). The second reason is that Porto Maravilha seems targeted at tourists and the middle class, offering relatively fewer benefits to nearby low-income residents. (It is possible, however, that, as with the Aterro do Flamengo, today's middle-class benefits become more accessible to low-income cariocas over time.) The third reason is that, from an engineering standpoint, Porto Maravilha is a larger, more complicated and longer project than Parque Madureira. Its financial and inconvenience costs are immediate and obvious. Its benefits are still uncertain.

The other major components in the Olympian transformation are the athletic venues and the Olympic village. There are several clusters of athletic venues, with the greatest concentration located in the Barra da Tijuca district, also the site of the Olympic village. As with Porto Maravilha, plans for the Olympic village and adjacent venues called for extensive favela removal, triggering resistance and controversy. Residents of the Asa Branca favela, initially slated for Olympian removal, successfully negotiated continued permanence in place, and may even stand to benefit from improved transportation and facilities in the surrounding area. The nearby favela of Vila Autôdromo, in contrast, sits directly adjacent to the Olympic Village, and its residents have faced greater threats and risks. As in Providência, organized resistance and successful mobilization of social movement and media allies has staved off the most drastic threats of complete removal. But it remains likely that much of Vila Autôdromo 
will be removed, and that remaining residents will largely be excluded from any potential benefits of Olympic construction.

The Olympic Village and the athletic venues appear to offer little benefit as a post-Olympic legacy to the citizens of Rio de Janeiro. Most of the venues will be meaningless or off-limits to Rio's citizens. If Olympian tradition holds, and nothing suggests it will not, most of them will fall into disuse immediately after the games. The Olympic Village will become middle-class apartment towers in a neighborhood already dominated by middle-class apartment towers, suffering a near absence of formal housing for low-income residents. Its construction has already exacerbated conflict between low-income and middle-class residents in this part of the city.

\section{Conclusion}

Parque Madureira is the best face of Rio's Olympian transformation. It already serves a low-income population, and does so with verve and environmental ingenuity. But it is not exceptional. Like the other Olympian projects, Parque Madureira emphasizes fun, fitness, sustainability, circulation and accessibility-with the contrast that it actually delivers on these goals. Understanding this helps to put both Parque Madureira and the broader transition in perspective. Parque Madureira is not as great as its most impassioned supporters suggest, and will probably not be as enduring. And the greater Olympian makeover may not be as catastrophic as many fear.

What does the relative success of Parque Madureira imply about favela removal? Does this mean that favela removal is back on the table, not only as a tool of an elitist administration in cahoots with real-estate speculators, but as a legitimate tool of urban planning? That would be tragic. Parque Madureira is a good park, maybe even in a great one. But the inscrutable process of the removal of Vila das Torres reminds us that 
real democratic inclusion in Rio requires the creation of legal space, as much as green space. Parque Madureira's relative success demonstrates that even a deeply flawed process can sometimes generate positive results, on balance. How much better could those results be, across the city, if the process were improved?

\section{Bibliography}

Bahia, Silvana. Resistência, mobilização e articulação contra as remoções forçadas no Rio, Observatório de Favelas, 28 October 2013. http://observatoriodefavelas.org.br/noticias-analises/resistencia-mobilizacao-earticulacao-contra-as-remocoes-forcadas-no-rio/ (last checked 07/05/2016)

Bonelli, Mauro Chagas. "Sustentabilidade em Obras Públicas: O Caso do Parque Madureira," Dissertação de Mestrado, Engenharia Urbana e Ambiental, PUC-Rio, 2013. http://www.urb.puc-rio.br/dissertacao/dissertacao_mauro_bonelli.pdf (last checked 07/05/2016)

Cardoso, Adauto; Nunes Junior, Décio Rodrigues; Araújo, Flávia de Sousa; Silva, Nathan Ferreira da; Jaenisch, Samuel Thomas. "Quando um direito vira produto: impactos do programa Minha Casa Minha Vida na cidade do Rio de Janeiro," XIII Simpósio Nacional de Geografia Urbana, 2013. http://docplayer.com.br/4150219Quando-um-direito-vira-produto-impactos-do-programa-minha-casa-minha-vida-nacidade-do-rio-de-janeiro-1.html (last checked 07/05/2016)

Joseph, Mary Allison. "A Walk Through Vila das Torres," Part Two, RioOnWatch, 5 Jan 2011. http://www.rioonwatch.org/?p=510 (last checked 07/05/2016)

Kimmelman, Michael "A Divided Rio de Janeiro, Over-reaching for the World," New York Times, Nov. 13 2015. http://www.nytimes.com/2013/11/26/world/americas/adivided-rio-de-janeiro-overreaching-for-the-world.html?pagewanted=all\&_r=0 (last checked 07/05/2016)

Magalhães, Luiz Ernesto. "Para implantar Transolímpico, Rio terá uma das maiores remoções de favelas desde 2009" 
Magalhães, Alexandre O "legado" dos megaeventos esportivos: a reatualização da remoção de favelas no Rio de Janeiro. Horiz. antropol. [online]. 2013, vol.19, n.40 [cited 2015-03-31], pp. 89-118. http://www.scielo.br/scielo.php?script=sci_arttext\&pid=S010471832013000200004\&lng=en\&nrm=iso. ISSN 0104-7183. http://dx.doi.org/10.1590/S010471832013000200004. (last checked 07/05/2016)

Mary Allison Joseph, “A Walk Through Vila das Torres," RioOnWatch, 27 Dec 2010, http://www.rioonwatch.org/?p=444 (last checked 07/05/2016)]

O Globo, 16 July 2014. http://oglobo.globo.com/rio/para-implantar-transolimpico-riotera-uma-das-maiores-remocoes-de-favelas-desde-2009-13271290 (last checked 07/05/2016)

Rezende, Ruy. "Parque Madureira," Projeto, Instituto de Arquitetos do Brasil, 2013 http://www.iab.org.br/projetos/parque-madureira (last checked 07/05/2016)

Santos, Rafael Fernandes dos. "Situação Atual e Perspectivas de Desenvolvimento da Area de Planejamento 3 da Cidade do Rio de Janeiro," Dissertação de Mestrado, Engenharia Urbana e Ambiental, PUC-Rio, 2012. http://www.urb.pucrio.br/dissertacao/dissertacao_rafael_fernandes.pdf (last checked 07/05/2016)

Sousa, Marcos de. "Lá na praia de Madureira," Revista Prisma, 31 Oct 2013. http://www.revistaprisma.com.br/novosite/noticia.asp?cod=6454 (last checked 07/05/2016)

Sousa, Mônica. "Praia versus Subúrbio: a mobilidade carioca em xeque," Leituras do Jornalismo, 1, 2014.

http://www2.faac.unesp.br/ojs/index.php/leiturasdojornalismo/article/view/2 (last checked 07/05/2016)

Silva, Laerte Costa. “O Ônus da construção de um espaço público de lazer no subúrbio carioca: remoções e valorização imobiliária associadas ao Parque Madureira." Encontros Nacionais da ANPUR. v.15 (2013) 